\title{
Fine structural changes in the epididymal epithelium of moles (Talpa europaea) throughout the year
}

\author{
Fumie Suzuki* and P. A. Racey $\dagger$ \\ Unit of Reproductive Biology, University of Liverpool, \\ P.O. Box 147, Liverpool L69 3BX, U.K.
}

\begin{abstract}
Summary. The epididymis of the European mole (Talpa europaea) was studied by light and electron microscopy. In the sexually active animal, spermatozoa mature during their passage through the epididymis and the structure of the cells lining the duct suggests a clear regional division into initial, middle and terminal segments. Numerous intra-epithelial vesicles were present in the distal part of the middle segment of sexually active moles and the lining epithelium in the terminal segment appeared to be secretory.

Variation in the sensitivity of different regions of the epididymis to androgens was apparent: the principal cells of the initial segment were morphologically active only during the peak of the breeding season in spring, while the cells of the terminal segment became active earlier and remained so for longer.

During sexual regression, many autophagic vacuoles were found in the principal cells, and these became transformed into lipofuscin pigment granules. Cells heavily laden with these granules appeared concurrently in the lining epithelium. It is suggested that such cells may be involved in the regression of principal cells by means of heterophagic activity. A similar situation was also observed, but to a lesser extent, at the beginning of the breeding season.

Outside the breeding season, the organelles of the principal cells were poorly developed throughout the epididymis, and lipofuscin pigment granules remained in the principal and basal cells of adults. Such granules were seldom seen in immature animals.
\end{abstract}

\section{Introduction}

Conspicuous regional differences in the structure of the epididymis have been repeatedly described (Hammar, 1897; Nicander, 1957, 1958), and Glover \& Nicander (1971) have suggested that histologically, cytologically and functionally the epididymis should be divided into three main regions: initial, middle and terminal segments. These segments do not necessarily correspond to the traditional terms of caput, corpus and cauda epididymidis, nor is it known whether the new terms are applicable to all mammalian epididymides.

In continuously breeding laboratory animals, research on the hormonal regulation of epididymal function has frequently involved removal of the testes and hormone replacement therapy (Hamilton, Jones \& Fawcett, 1969). In seasonal breeders, however, hormonal changes occur more gradually and the intermediate stages of activation and regression of the epididymal epithelium can be examined. The European mole, Talpa europaea, which has a distinct breeding season (Allanson, 1963), was therefore chosen for an examination of all stages of the epididymal cycle. The investigation also provided an opportunity to determine the sensitivity of the epididymis to androgens at different stages of the reproductive cycle.

* Present address: Department of Anatomy, School of Medicine, University of Chiba, Chiba 280, Japan.

$\dagger$ Present address and address for reprints: Department of Zoology, University of Aberdeen, Aberdeen AB9 2TN, U.K. 


\section{Materials and Methods}

Male moles (51) were caught at intervals of about 6 weeks for 1 year in the vicinity of Stallmine, Lancashire, England, $53^{\circ} 54^{\prime} \mathrm{N}, 2^{\circ} 57^{\prime} \mathrm{W}$. Live animals were transported to the laboratory, and killed by decapitation. Immediately after death, the testes and epididymides of 23 animals were fixed in $2.5 \%$ phosphate-buffered glutaraldehyde. Particular care was taken to remove the muscular sac which invests the terminal segment of the epididymis in this species (Text-fig. 1). After initial fixation, small pieces of tissue were selected for electron microscopy from the testis and from four different parts of the epididymis (see Text-fig. 1) of all animals. Two of the most sexually active animals (Nos 44 and 45), caught on 11 March were examined at 20 different places along the excurrent duct, including efferent ductules and ductus deferens. Tissues were post-fixed in $1 \%$ phosphate-buffered $\mathrm{OsO}_{4}$, dehydrated in ethanol and embedded in Epon 812. Thick sections, cut with glass knives, were stained with toluidine blue and examined with a light microscope. Thin sections, cut with a diamond knife, were mounted on uncoated copper grids, stained with aqueous uranyl acetate followed by lead citrate and examined in a JEM7A or Hitachi 11-DS electron microscope.

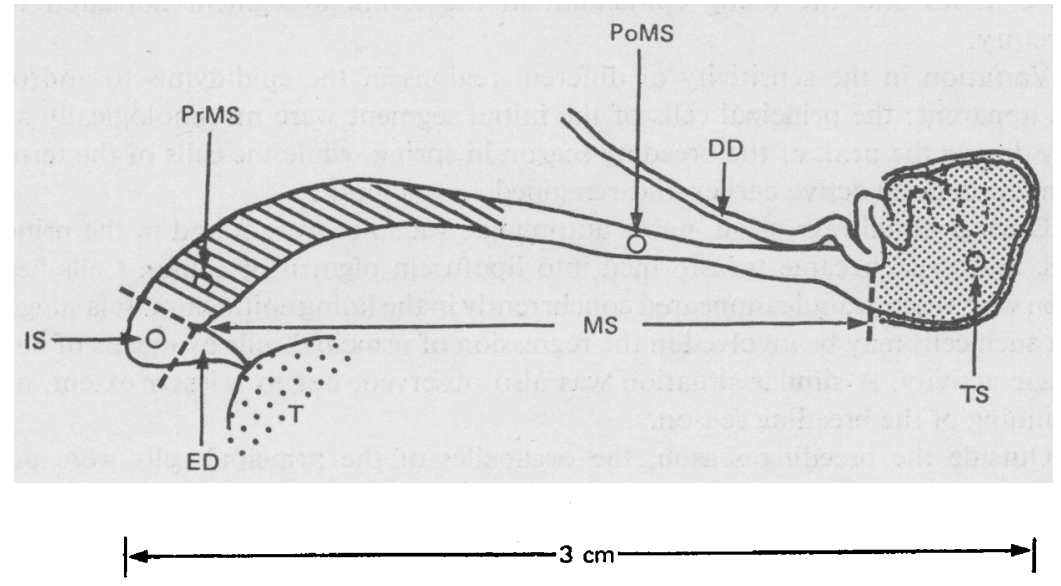

Text-fig. 1. A diagrammatic representation of the epididymis of the sexually active male mole. The division between proximal, middle and terminal segments is shown by the broken lines; open circles $(O)$ show the position of tissue collection throughout the year; cross-hatching shows the region where spermatozoa become highly concentrated; the stippled area represents that covered with the muscular sac. T, testis; ED, efferent ductules; IS, initial segment; MS, middle segment; PrMS, proximal part of middle segment; PoMS, posterior part of middle segment; TS, terminal segment; DD, ductus deferens.

\section{Observations}

The epididymal epithelium of adult moles was classified into four stages of activity depending upon whether the principal cell appeared to be developing, active, regressing or quiescent. Differences in the activity of the various regions throughout the year are summarized in Text-fig. 2 . The terminal segment became active earlier than the other parts of the duct and remained so for longer. In contrast, the initial segment maintained its active appearance for a relatively short time. Exceptionally, one mole caught in November (No. 28) had an active terminal segment, although the proximal part of the duct appeared quiescent.

\section{The sexually active mole}

Three moles caught on 11 March and one caught on 8 April had fully active epididymides (Textfig. 2). Light micrographs of different segments are shown in Pl. 1, Figs 1-4 and the main cytological 


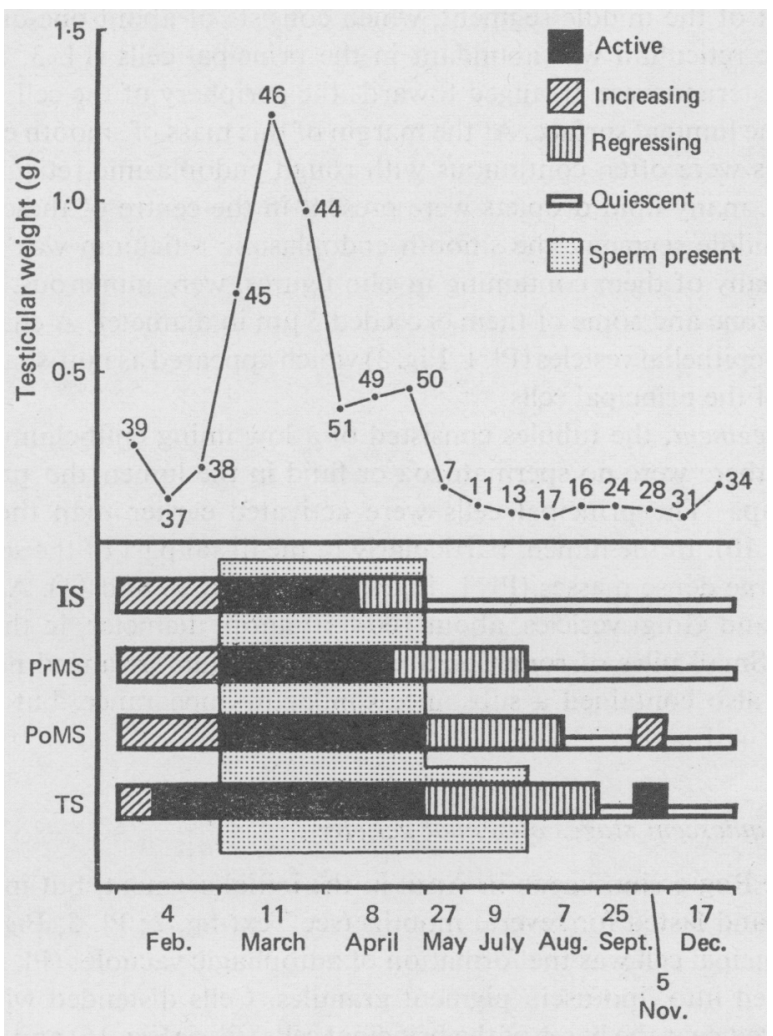

Text-fig. 2. The graph shows the change in weight of one testis of the adult moles used in the present study. The stage of activity of the corresponding epididymides at four different levels along the duct, as judged by the cytological features of the lining principal cells, is also indicated. The dates of collection are shown on the abscissa, and the figures at each point represent the number of the mole. IS, initial segment; PrMS, proximal part of middle segment; PoMS, posterior part of middle segment; TS, terminal segment.

characteristics of the principal cells in each region of the epididymis are summarized in Table 1. Spermatozoa were present in low density in the initial segment (PI. 1, Fig. 1) and much higher density in the proximal half of the middle segment (PI. 1, Fig. 2). The acrosomes of spermatozoa in the initial segment appeared tortuous in outline and cytoplasmic droplets were situated on the neck (PI. 2, Fig. 5). In the terminal segment, the acrosomes were condensed and filiform (PI. 2, Fig. 6) and the cytoplasmic droplet had migrated caudally. These morphological changes occurred in the spermatozoa as they reached the proximal part of the middle segment.

The epithelium lining the epididymis consisted of two major cell types-the stereociliated principal cells which predominated but varied in structure along the length of the duct, and basal cells with poorly developed organelles. Slender columnar cells and halo cells were seen occasionally. The columnar cell was easily distinguished from adjacent principal cells by its cytoplasm which contained many dense granules, lipid droplets and in some cases, glycogen.

In the initial segment, the star-shaped lumen contained electron-permeable fluid. The Golgi apparatus of the principal cells was particularly well developed and the basal cytoplasm of these cells contained abundant rough endoplasmic reticulum (Pl. 1, Fig. 1; Pl. 2, Fig. 7).

In the middle segment, the lumen was packed with spermatozoa suspended in an amorphous substance (PI. 1, Fig. 2). The principal cells of this segment contained absorbing vacuoles, which in many cases appeared as large multivesicular bodies (PI. 3, Fig. 8), although most were $<2 \mu \mathrm{m}$ in diameter. They were more numerous in the proximal part of this segment. Apart from the distribution of vacuoles, there were other differences between the proximal part and the rest of the middle segment, 
In the proximal part of the middle segment, which consists of about one-quarter of this segment, smooth endoplasmic reticulum was abundant in the principal cells (Pl. 3, Fig. 9). More than 10 layers of flattened cisternae were arranged towards the periphery of the cell, although they did not make contact with the luminal surface. At the margin of this mass of smooth endoplasmic reticulum, sheets of membranes were often continuous with rough endoplasmic reticulum. In the infra- and supra-nuclear zones, many lipid droplets were present in the centre of these membranous masses. In the rest of the middle segment, the smooth endoplasmic reticulum was poorly developed, but lysosomal bodies, many of them containing myelin figures, were numerous. They were distributed in the infranuclear zone and some of them exceeded $3 \mu \mathrm{m}$ in diameter. A characteristic feature was the presence of intra-epithelial vesicles (Pl. 1, Fig. 3) which appeared as puff-shaped spaces surrounded by the free surface of the principal cells.

In the terminal segment, the tubules consisted of a low lining epithelium, and at the beginning of the season when there were no spermatozoa or fluid in the lumen the principal cells were tall and irregular in shape. The principal cells were activated earlier than those of more proximal segments (Pl. 4, Fig. 10). In the lumen, particularly in the distal part of the segment, an amorphous substance formed large dense masses (Pl. 1, Fig. 4; Pl. 4, Figs 10 and 11). A similar substance was contained in apical and Golgi vesicles, about $100-150 \mathrm{~nm}$ in diameter, in the lining principal cells (Pl. 4, Figs 11-13). Small piles of rough endoplasmic reticulum arranged near the apical surface, and their cisternae, also contained a substance similar in appearance, but of lower density than that in the lumen (Pl. 4, Fig. 11).

\section{The transitional and quiescent stages of sexual activity}

Regressing stage. Regression began in April in the initial segment, but in the other parts of the duct it started later and lasted for several months (see Text-fig. 2; Pl. 5, Fig. 15). The first sign of regression of the principal cell was the formation of autophagic vacuoles (Pl. 5, Fig. 15, inset) which gradually transformed into lipofuscin pigment granules. Cells distended with such granules were frequently encountered near the bases of the principal cells (Pl. 6, Fig. 16) and direct contact between them and the basal lamina was sometimes observed. The volume of the principal cell, its Golgi apparatus, endoplasmic reticulum and the number and length of its stereocilia diminished gradually, and in the middle segment all vacuoles and smooth endoplasmic reticulum disappeared completely. Lipid droplets, which were common in this segment of the active epididymis, also decreased in number. As a result of these changes, the regional differences between principal cells were lost.

Quiescent stage. The luminal diameter of the epididymis diminished and the lining epithelium was very low. The lumen, either patent or nearly closed, contained only electron-permeable fluid (Pl. 4, Fig. 14; Pl. 7, Fig. 18). Small stacks of Golgi apparatus, small mitochondria, fragmented rough endoplasmic reticulum, centrioles and many free ribosomes were contained within the diminished cytoplasm. Short stereocilia appeared at the luminal surface of the principal cell. At the bases of the principal and basal cells many thin branches of cytoplasm were attached to the basal lamina, the folding of which resulted from a reduction in the diameter of the epididymal tubules. Some principal cells contained lipofuscin pigment granules derived from autophagic vacuoles, and many similar granules were seen in some of the true basal cells and also in the basal-like cells which were not attached to the basal lamina. In one mole (No. 24), a cell that was heavily laden with these granules was seen passing through a broken basal lamina (PI. 6, Fig. 17), and similar cells were scattered among subepithelial connective tissue. These features of the quiescent stage were observed throughout the epididymis, although a high lipid content characterized the lipofuscin pigment granules in the initial segment.

Outside the breeding season, from May to December, 5 moles were judged as immature by the virtual absence of lipofuscin pigment granules both from the epididymal epithelium and from the Sertoli cells.

Developing stage. The lining epithelium of the terminal segment of two of the three animals (Nos 37 and 38; see Text-fig. 2) caught on 4 February was already fully acțivated, and much secretory material was observed in the sperm-free lumen (Pl, 4, Fig. 10), 

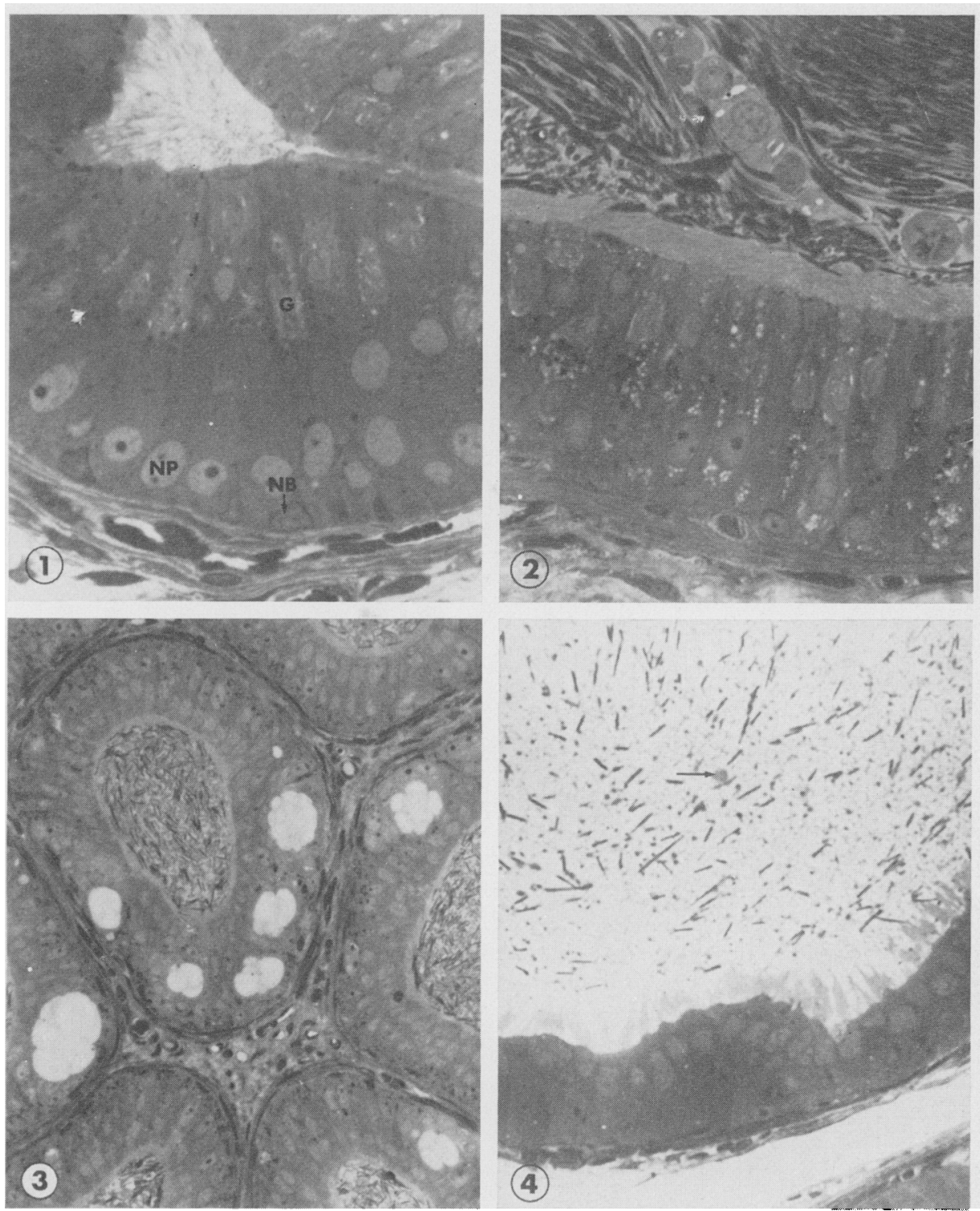

Photomicrographs of Epon sections from the epididymis of a sexually active mole. Toluidine blue staining.

Fig. 1. Initial segment: the star-shaped Jumen is occupied by the long stereocilia of the tali principal cells; the Golgi apparatus $(G)$ is clearly recognizable and there are no spermatozod in the lumen. NP, nucleus of principal cell: NB, nucleus of basal cell. $\times 810$.

Fig. 2. Proximal part of middle segment: the lumen is packed with spermatozoa, and sloughed spermatids are also present: stereocilia are lower than those of the initial segment: iysosomal granules appear as black spots mainly in the supranuclear region of the principal cells: and lipid droplets appear as white spots around the nucleus. $\times 720$.

Fig. 3. Posterior part of middle segment (corpus epididymidis): many intra-epithelial vesicles appear as white puff-like forms; and dense lysosomal granules are numerous in the infra-nuclear region. $\times 240$.

Fig. 4. Terminal segment: the spermatozoa in the lumen are reduced in density; the amorphous substance which is secreted by the epithelium is recognizable (arrow). The principal cells of this segment are much lower than those of the initial and middle segments. $\times 480$. 
PLATE 2

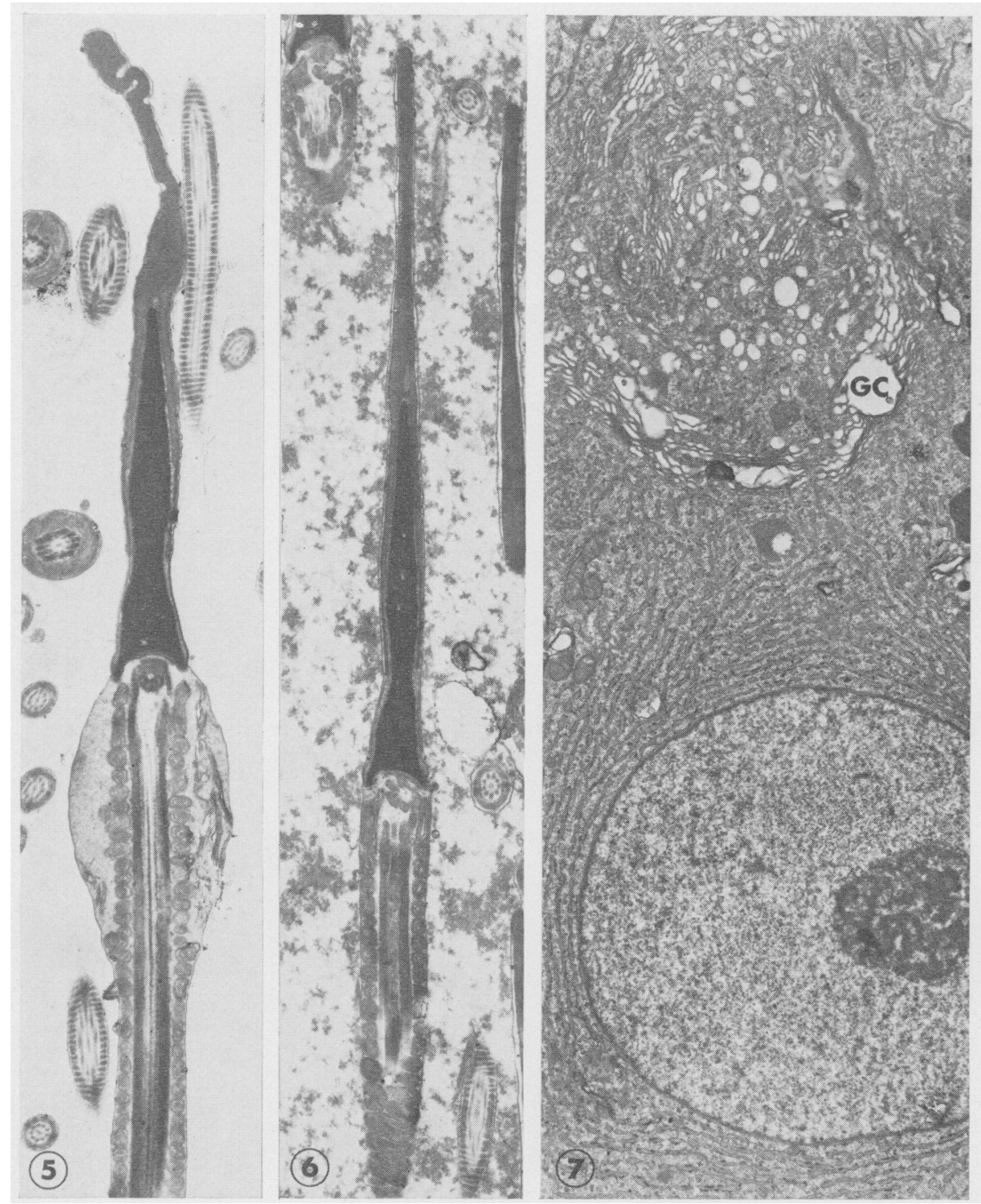

Fig. 5. Spermatozoon from the initial segment. The acrosome is irregular and the cytoplasmic droplet occurs at the neck. $\times 9000$.

Fig. 6. Spermatozoon from the proximal part of the terminal segment: the acrosome has condensed and appears filiform and the cytoplasmic droplet has migrated caudally. Note the amorphous substance surrounding the spermatozoon. $\times 9000$.

Fig. 7. Active principal cell of the initial segment: the Golgi apparatus and rough endopiasmic reticulum are well developed in this area. GC, Golgi cistern swollen by fixation artifact. $\times 7200$. 

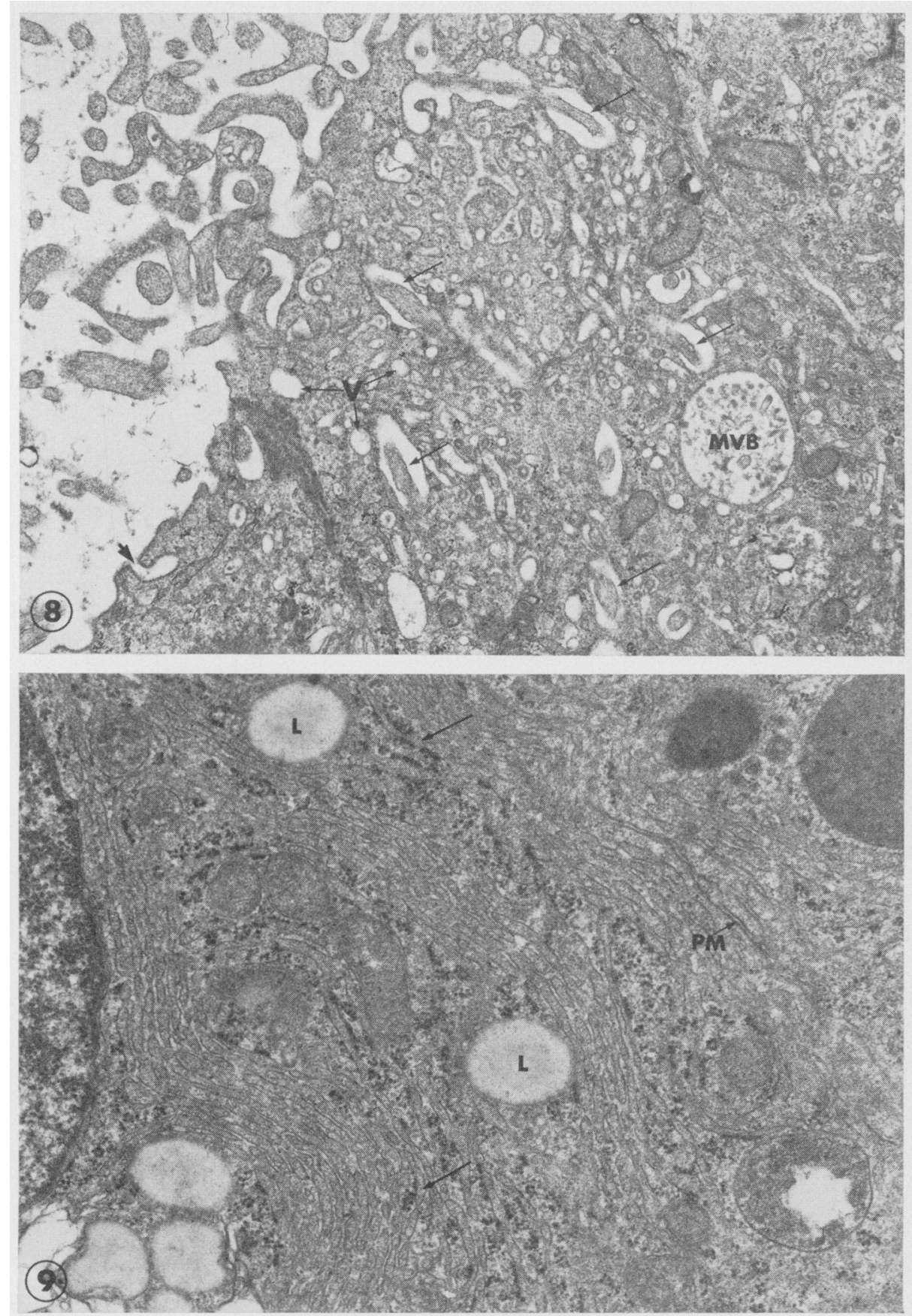

Fig. 8. Apical surface of an active principal cell in the proximal part of the middle segment. Pinocytosis vesicles (arrow head) and various sizes of vacuoles $(V)$ are seen. A large vacuole contains many internal vesicles (MVB). Stereocilia, seen here in oblique section, are frequently found in the cytoplasm (arrows). They may be engulfed by vigorous inward movement of the apical surface membrane. $\times 21,000$.

Fig. 9. Nuclear region of a principal cell in the proximal part of the middle segment. Smooth endoplasmic reticulum is abundant in this area and the membrane is continuous with that of the rough-surfaced endoplasmic reticulum (arrows). Many lipid droplets (L) are associated with the smooth endoplasmic reticulum. $P M$, plasma membrane. $\times 23,100$. 


\section{PLATE 4}
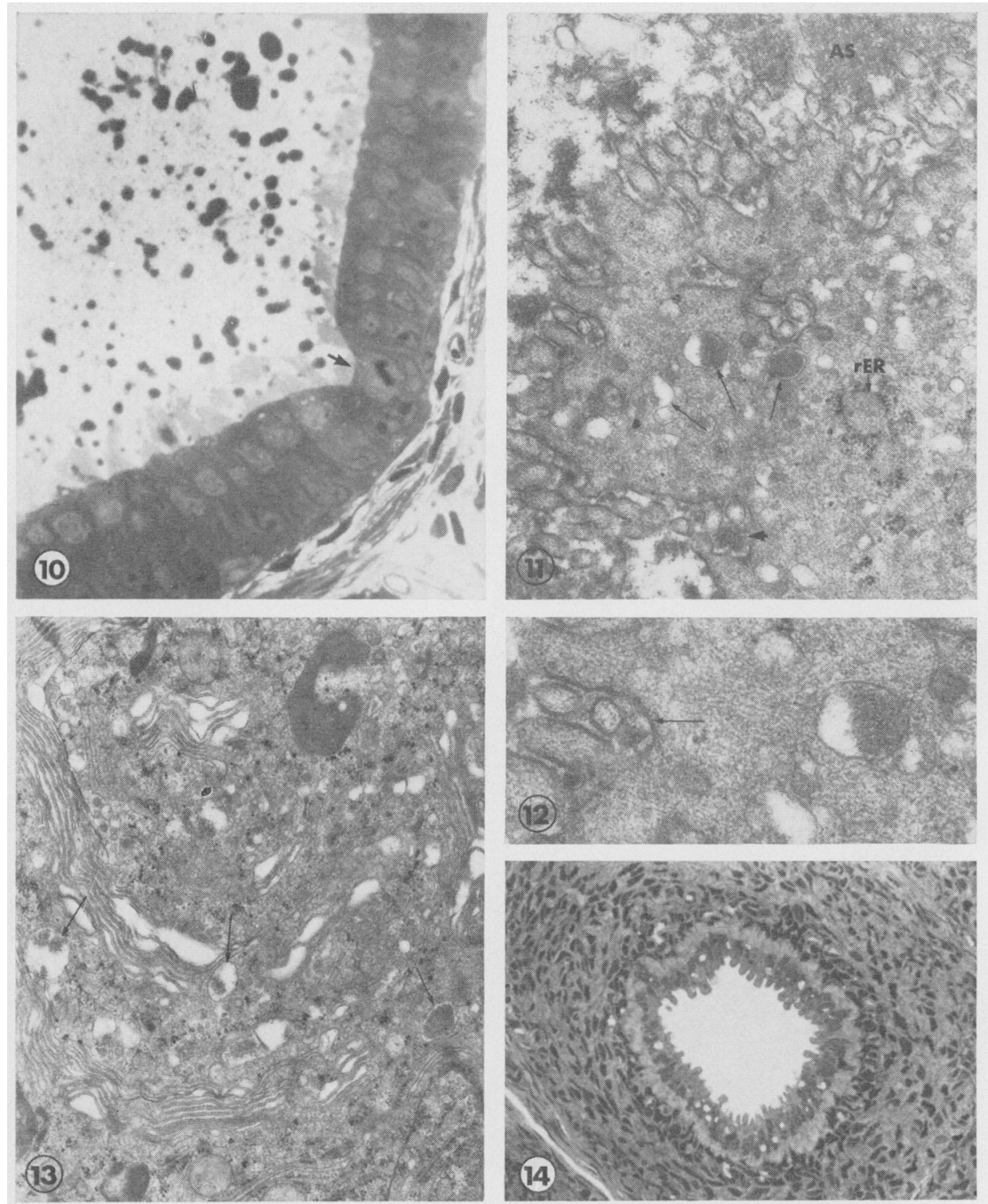

The terminal epididymal segment (cauda epididymidis), at the beginning of the breeding season (Figs 10-13) and during sexual quiescence (Fig. 14).

Fig. 10. Many secretion granules are seen in the sperm free lumen (compare Fig. 14). The arrow points to a dividing cell, which is commonly observed at the beginning of the breeding season. Toluidine blue, $\times 660$.

Fig. 11. Apical surface of the principal cell. The secretion granules seen in Fig. 10 are clearly amorphous and not membrane-bound (AS). Similar material occurs in the apical vesicles (arrows) and in the cisterna of rough endoplasmic reticulum (rER) of the principal cell. The electron density of the contents in the rER is lower than that of the luminal substance. The substance may be secreted by exocytosis (arrow head). $\times 19,200$.

Fig. 12. Higher magnification of Fig. 11. Note the secretion granule, the membrane of which appears thinner than the plasma membrane (arrow). $\times 42,000$.

Fig. 13. Golgi region of the principal cell. Amorphous substance, similar to that shown in Fig. 11, is also present in the Golgi vacuoles (arrows). $\times 14,400$.

Fig. 14. Terminal segment showing the complete absence of amorphous substance in the lumen. Toluidine blue, $\times 340$. 


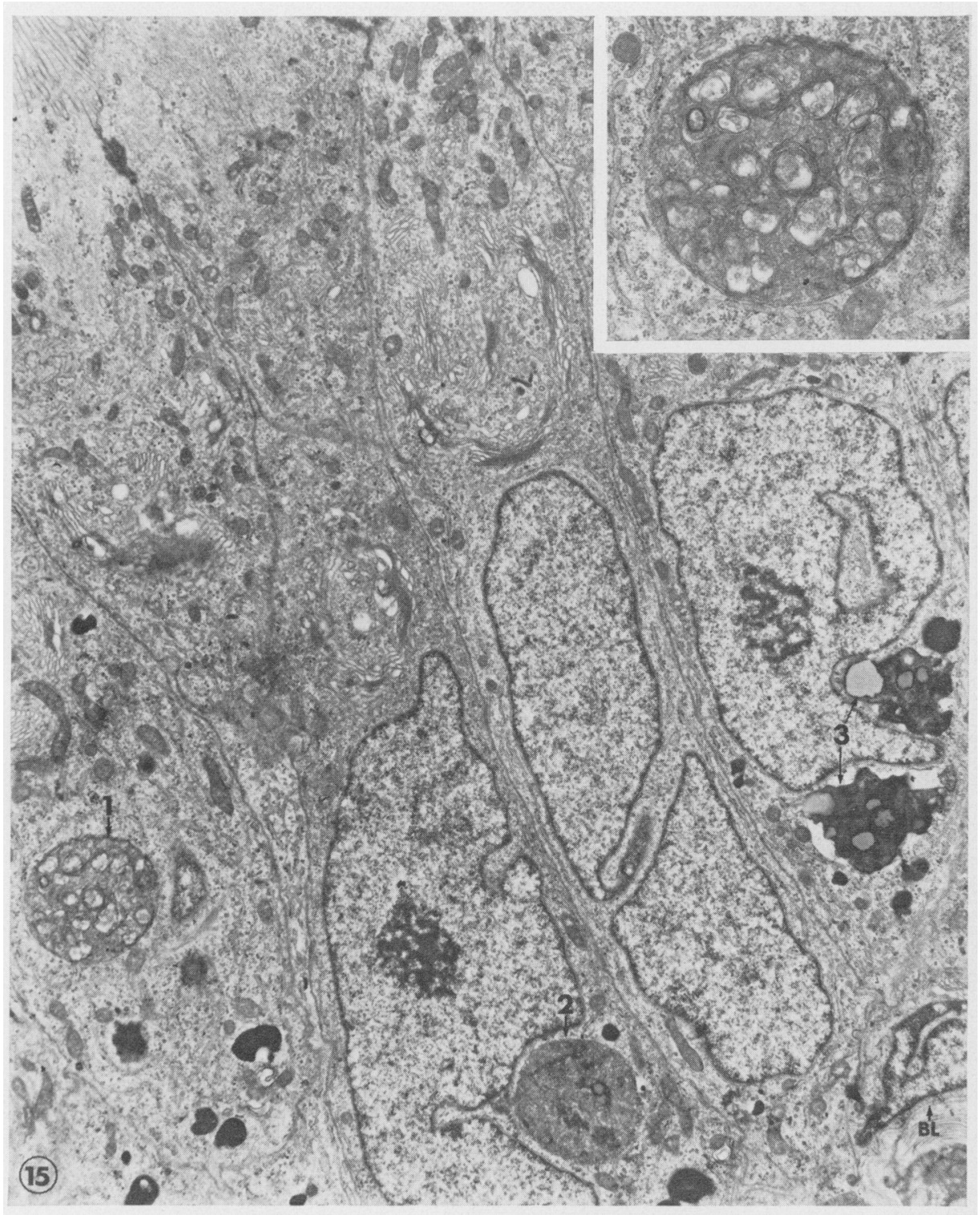

Fig. 15. Regressing principal cells of the distal part of the middle segment. Construction of the organelles is still well maintained, but many autophagic vacuoles have appeared in the cy toplasm. Membranous whorls are recognizable in the newly formed vacuole (No. 1 and inset). Vacuoles 2 and 3 are more advanced forms. BL, basail lamina. $\times 5640$; inset, $\times 13,800$. 

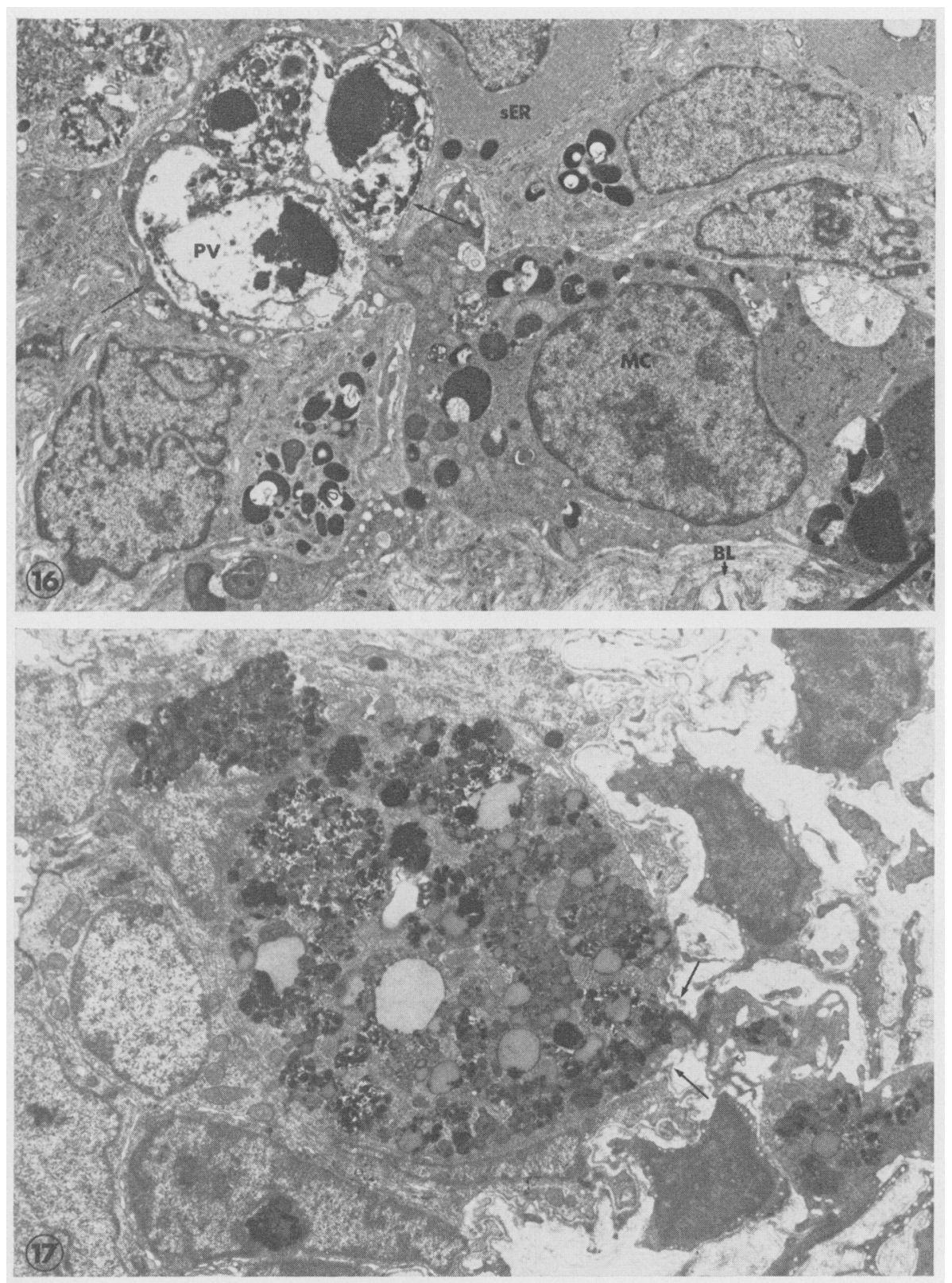

Fig. 16. Regressing stage of the proximal part of the middle segment. One macrophagic cell (MC) which is situated close to the basal lamina (BL) appears to encircle the phagocytic vacuoles (PV) with thin cytoplasmic projections (arrows). sF. s, smooth endoplasmic reticulum of principal cell. $\times 4800$.

Fig. 17. The epididymal epithelium in the proximal part of the middle segment of the sexually quiescent mole showing a cell heavily loaded with lipofuscin pigment granules passing into the interstitial tissue through the break in the basal lamina (arrosed). $\times 6000$. 


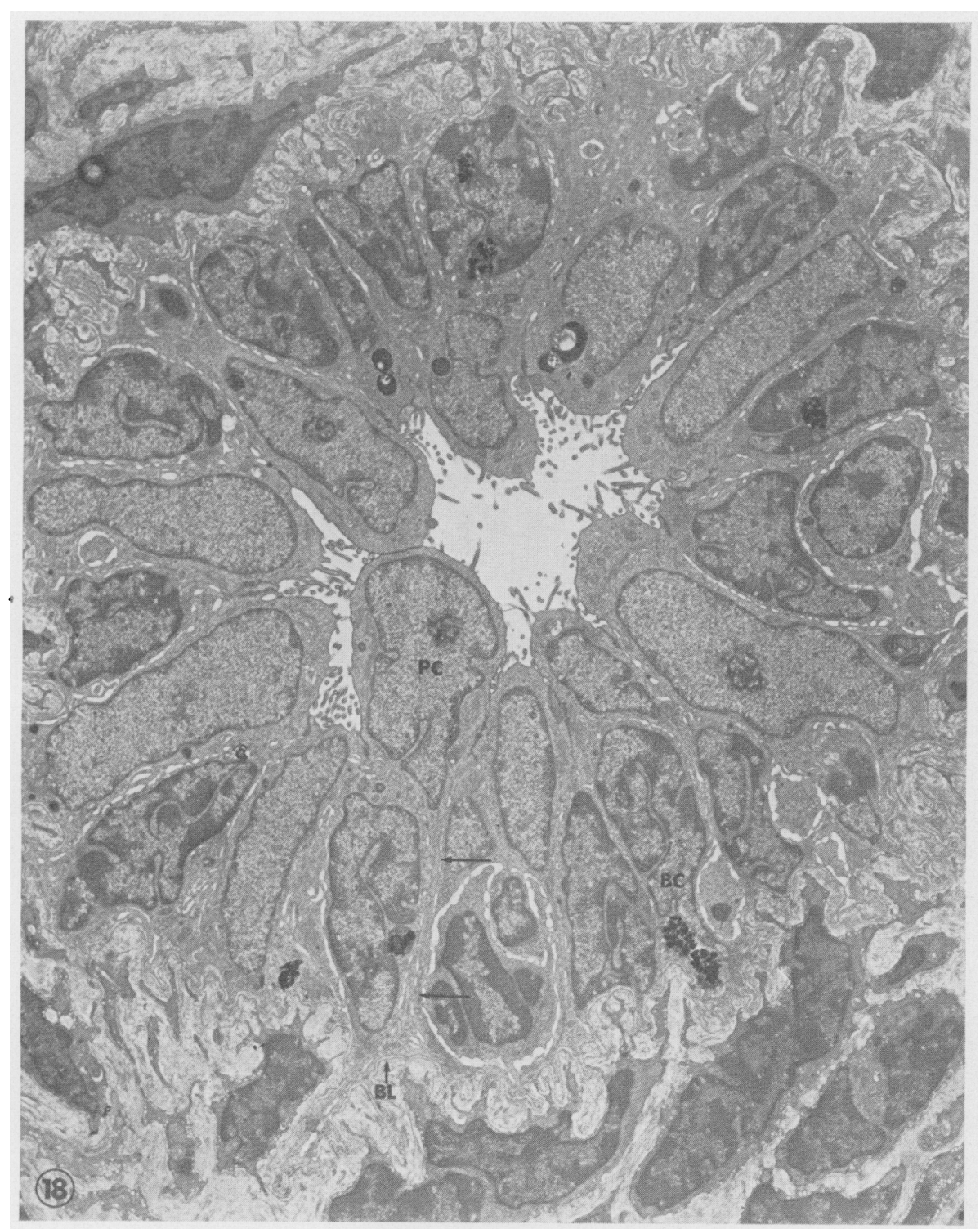

Fig. 18. The epididymal epithelium in the proximal part of the middle segment of the sexually quiescent mole. Principal cells ( $P C$ ) have poorly developed cytoplasm. Even when the main part of the cell body projects into the lumen, the principal cell maintains contact with the basal lamina (BL) through thin stalks (arrows). Residual lipofuscin pigment granules are seen in the principal and basal cells $(B C)$. The basal lamina is greatly corrugated because of the reduction in tubular diameter. $\times 3900$. 


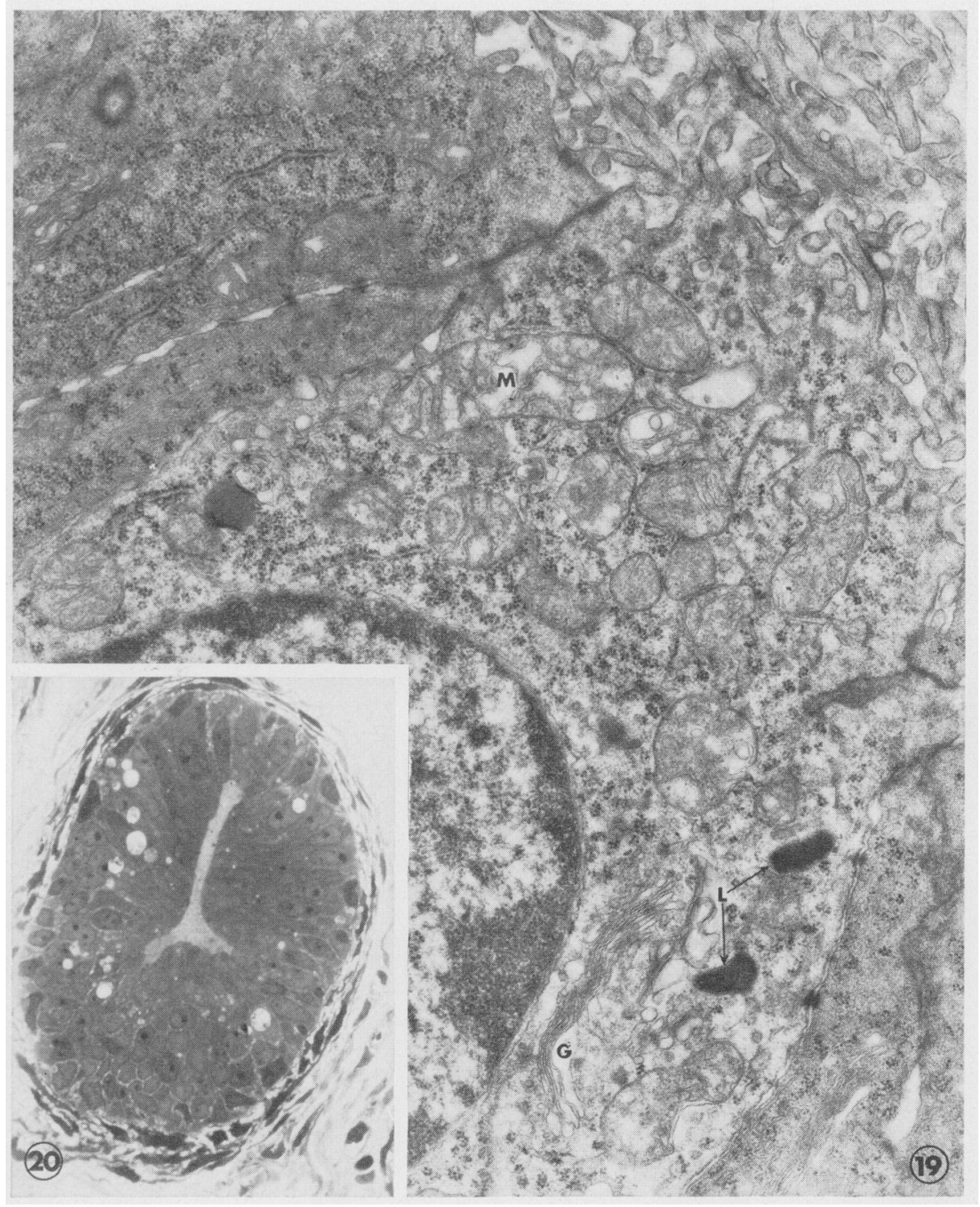

Figs 19 and 20. The epididymal epithelium in the proximal (Fig. 19) and the distal (Fig. 20) part of the middle segment during the developing stage. The terminal segment of this animal (Mole 38 ) was fully active (see Pl. 4, Figs 10-13).

Fig. 19. The apical half of the principal cell. Free ribosomes, rough endoplasmic reticulum and mitochondria (M) dominate the cytoplasm, but the Golgi apparatus $(G)$ is still small. L, lysosomes. $\times 16,800$.

Fig. 20. Autophagic vacuoles appear in the principal cell during an advanced stage of their development. The image in the electron microscope is similar to that shown in PI. 5, Fig. 15. Toluidine blue, $\times 540$. 
During the first stage of activation many lipofuscin pigment granules could still be seen in the lining epithelium, although they later disappeared. The position of the nucleus varied within the principal cell, resulting in so-called pseudostratification, and there was also considerable variation in the density of the nuclei and cytoplasm of these cells (P1. 8, Fig. 19) which assumed a characteristic columnar appearance as the volume of the cytoplasm increased.

The most distinct change was the increase in number of free ribosomes and mitochondria and in amount of rough endoplasmic reticulum in the cytoplasm of the principal cells. The Golgi apparatus, lysosomal bodies and stereocilia increased only gradually (PI. 8, Fig. 19). In the initial segment many microtubules made a transitory appearance in the expanding cytoplasm. In the middle segment, characteristic absorbing vacuoles appeared, but development of the smooth endoplasmic reticulum and the accumulation of lipid droplets lagged behind the organization of other cell organelles.

In the later stages of development, large membrane-bound vacuoles appeared in the cytoplasm of the principal cells (P1. 8, Fig. 20). They were more frequently encountered in the initial segment and in the posterior part of the middle segment, and were obviously newly formed autophagic vacuoles, since they contained recognizable cell organelles or cell debris. Cells distended with many such vacuoles appeared in the intercellular space of the epididymal epithelium, but on a smaller scale than was seen during the subsequent regressing stage.

\section{Discussion}

Mole testes are situated in ventral abdominal pouches and appear to be intermediate in position between those of testicond and scrotal mammals. The present observations, however, show that the fine structure of the epididymis of the sexualiy active mole is similar to that of true scrotal mammals, such as the rabbit (Nicander, 1965), or hamster (Nicander \& Glover, 1973). The characteristics of different regions of the duct (Table 1) correspond well with the description of the three segments given by Glover \& Nicander (1971). These workers pointed out that spermatozoa became concentrated in the lumen of the middle segment, indicating that fluid absorption occurs during maturation of the spermatozoa. In the epididymis of the sexually active mole, concentration of spermatozoa in the middle segment is obvious, and morphological changes in the spermatozoa correlating with sperm maturation are apparent during their passage through this segment (PI. 2, Figs 5 and 6).

Table 1. The main cytological characteristics of the epididymal principal cell in the sexually active mole

\begin{tabular}{|c|c|c|c|c|}
\hline Organelles* & Initial segment & $\begin{array}{l}\text { Proximal part of } \\
\text { middle segment } \\
\text { (caput) }\end{array}$ & $\begin{array}{l}\text { Posterior part of } \\
\text { the middle segment } \\
\text { (corpus) }\end{array}$ & $\begin{array}{l}\text { Terminal segment } \\
\text { (cauda) }\end{array}$ \\
\hline Stereocilia & Long and irregular & Long and whip like & Short and slender & Short and slender \\
\hline $\begin{array}{l}\text { Large vacuoles } \\
\text { (over } 1 \mu \mathrm{m} \text { ) }\end{array}$ & - & ++ & $+t$ & - \\
\hline Golgi apparatus & $+1++$ & +++ & ++ & $++t$ \\
\hline $\begin{array}{l}\text { Rough } \\
\text { endoplasmic } \\
\text { reticulum }\end{array}$ & $\begin{array}{c}++++ \\
\text { (Nissl body like) }\end{array}$ & ++ & ++ & ++ \\
\hline $\begin{array}{l}\text { Smooth } \\
\text { endoplasmic } \\
\text { reticulum }\end{array}$ & $\begin{array}{c}+ \\
\text { (fragments of small } \\
\text { tubules) }\end{array}$ & $\begin{array}{l}+++ \\
\text { (arrays of flattened } \\
\text { cisternae) }\end{array}$ & $\begin{array}{c}+ \\
\text { (fragments of small } \\
\text { tubules) }\end{array}$ & $\begin{array}{c}+ \\
\text { (fragments of tubules } \\
\text { or flattened cisternae) }\end{array}$ \\
\hline \multicolumn{5}{|l|}{ Lysosomal bodies } \\
\hline Number & $+t$ & +++ & +++ & ++ \\
\hline Main distribution & $\begin{array}{l}\text { Scattered in the } \\
\text { basal half }\end{array}$ & Golgi zone & Infranuclear zone & Infranuclear zone \\
\hline Lipid droplets & ++ & $+t+$ & + & + \\
\hline Mitochondria & Thin rod & Thick rod & Thick rod & Thick rod \\
\hline $\begin{array}{l}\text { Cell height (excluding } \\
\text { stereocilia) }\end{array}$ & $45-70 \mu \mathrm{m}$ & $40 \mu \mathrm{m}$ & $35 \mu \mathrm{m}$ & $28 \mu \mathrm{m}$ \\
\hline
\end{tabular}

* Numbers of organelles and their development were scored on an arbitrary scale from + to ++++ : 
The division of epididymal function as outlined by Glover \& Nicander (1971) appears to be valid for the mole. Nevertheless the present work shows that the mole epididymis has certain unusual characteristics. For example, the absorbing vacuoles of the principal cells (Pl. 3, Fig. 8), which have been described as characteristic cell organelles of the middle segment (Glover \& Nicander, 1971), are much smaller and more sparsely distributed than in the epididymis of the rat (Reid \& Cleland, 1957), rabbit (Nicander, 1965), or hamster (Nicander \& Glover, 1973). In addition, although smooth endoplasmic reticulum is prominent in the principal cells of many mammalian epididymides (see Hamilton, 1971), extensive development of this organelle in the mole is limited to the proximal part of the middle segment (PI. 3, Fig. 9). In these respects, the epididymis of the mole is cytologically more simple than that of true scrotal mammals. Intra-epithelial vesicles (Pl. 1, Fig. 3) are numerous in the mole epididymis and are also common in the epididymis of another insectivore, the hedgehog (Erinaceus europaeus), during the breeding season (F. Suzuki \& P. A. Racey, unpublished observations). Similar vesicular structures have been reported in the epididymal epithelium of the cat (Scott, Greaves \& Scott, 1960) and man (Holstein, 1969). In golden hamsters, similar vesicles appeared in the epididymis within 1 week of bilateral gonadectomy, although their appearance was delayed by the administration of testosterone; they also occurred some weeks after experimental cryptorchidism (Suzuki, 1974). The vesicles are mostly located between the distal part of the middle segment and the proximal part of the terminal segment in moles, hedgehogs and hamsters. In the hamster, the vesicles appear to be formed by fusion of folded epithelium since they contain either spermatozoa or clearly identifiable parts of spermatozoa (Suzuki, 1974). In the mole and hedgehog, however, such vesicles were empty, perhaps because they form before the first spermatozoa reach the epididymis at the beginning of the breeding season.

Macrophagic activity of the basal cells has been found in the regressing epididymal epithelium of the gonadectomized hamster (Suzuki \& Glover, 1973). Cells heavily laden with lipofuscin pigment granules appeared in the regressing epididymal epithelium of the mole (PI. 6, Fig. 16) and regression appears to be the result of heterophagic as well as autophagic activity, as in the involuting mammary gland (Helminen \& Ericsson, 1968). The heterophagic cell of the mole might have originated as a basal cell, as in the gonadectomized hamster, but contact with the basal lamina was infrequently observed.

Although the epididymal epithelium is known to secrete many substances, such as glycerylphosphorylcholine, protein and PAS-positive substances (Jones \& Glover, 1975), morphological evidence for secretion is limited. Although blebs on the surface of the principal cells have been associated with secretion by Holstein $(1964,1969)$, Nicander $(1970)$ has produced good evidence that they are artifacts of fixation. Present observations on the terminal segment of the mole epididymis indicate, however, that secretion does occur, for in the sexually quiescent mole the lumen is either empty or contains electron-permeable fluid (Pl. 4, Fig. 14), while at the beginning of the breeding season, before any spermatozoa have arrived in the epididymis, the lumen is full of amorphous granular material (PI. 4, Fig. 10). Such material is also seen in vacuoles around the Golgi apparatus (PI. 4, Fig. 13) and in apical vacuoles of the epithelial cells (Pl. 4, Figs 11 and 12) and appears to be a secretion. Although the secretion product probably arises by activity of the Golgi apparatus in the mole, its direct release from cisternae of the endoplasmic reticulum, as has been suggested for the rat by Hoffer, Hamilton \& Fawcett (1973), cannot be altogether discounted.

During the course of the breeding season, the various regions of the epididymis appeared to differ in sensitivity to androgens, since the more distal regions of the duct were active for longer than the more proximal regions (Text-fig. 2). The terminal segment maintains its activity for a longer period than the rest of the duct, and in one mole (No. 28) the lining cells of the sperm-storing terminal segment were active well beyond the end of the breeding season. In another seasonal breeder, the rock hyrax, spermatozoa are also stored in the terminal segment for some time after the testis has started to regress (Millar, 1972). In the extreme case of some vespertilionid bats, fertile spermatozoa are stored in the terminal segment of the epididymis for up to 7 months after the cessation of spermatogenesis (Racey, 1973). Since the normal activity of the epididymis is dependent upon circulating androgens, and since this activity is in turn vital to sperm survival in the epididymal duct (Lubicz-Nawrocki \& Glover, 1973; Jones \& Glover, 1973; Glover, Suzuki \& Racey, 1974), 
it is appropriate that the cells lining the terminal segment where spermatozoa are stored have a continuing androgen requirement. Neither is it surprising to find that testicular androgenesis continues, albeit at low levels, during sperm storage (Racey, 1974).

The cells of the terminal segment do eventually regress and stored spermatozoa are eliminated. At the end of the breeding season, therefore, regressive changes in the epithelium occur throughout the epididymal duct, with disintegration of cell organelles, reduction of cell volume, the formation of autophagic vacuoles and their transformation into numerous lipofuscin pigment granules (PI. 5, Fig. 15). These changes are similar to those following bilateral gonadectomy (Suzuki \& Glover, 1973), except that they take longer, a clear correlation with androgen levels which fall gradually in seasonally breeding mammals (Racey, 1974) and decline rapidly after bilateral gonadectomy (Rowe, Shenton \& Glover, 1973).

The work was supported by a grant from the Ford Foundation. We thank Dr T. D. Glover for his interest in this study and Mrs G. P. Boyd for technical assistance.

\section{References}

Allanson, M. (1963) The reproductive tract of prepubertal and mature male moles during the anoestrus. $J$. Endocr. 26, ix.

Glover, T.D. \& Nicander, L. (1971) Some aspects of structure and function in the mammalian epididymis. J. Reprod. Fert., Suppl. 13, 39-50.

Glover, T.D., Suzuki, F. \& Racey, P.A. (1974) The role of epididymal cells in sperm survival. In The Functional Anatomy of the Spermatozoon, pp. 359-371. Ed. B. Afzelius. Wenner-Gren, Stockholm.

Hamilton, D.W. (1971) The mammalian epididymis. In Reproductive Biology, pp. 268-337. Eds $H$. Balin \& S. G. Glasser. Excerpta Medica, Amsterdam.

Hamilton, D.W., Jones, A.L. \& Fawcett, D.W. (1969) Cholesterol biosynthesis in the mouse epididymis and ductus deferens: a biochemical and morphological study. Biol. Reprod. 1, 167-184.

Hammar, J.A. (1897) Über Secretionsercheinungen im Nebenhoden des Hundes. Arch. Anat. EntwGesch. 1, Suppl. 1, 1-42.

Helminen, H.J. \& ERICsson, J.L.E. (1968) Studies on mammary gland involution. II. Ultrastructural evidence for auto- and heterophagocytosis. $J$. Ultrastruct. Res. 25, 214-227.

Hoffer, A.P., Hamilton, D.W. \& Fawcett, D.W. (1973) The ultrastructure of the principal cells and intraepithelial leucocytes in the initial segment of the rat epididymis. Anat. Rec. 175, 169-202.

Holstein, A.F. (1964) Elektronenmikroskopische Untersuchungen Nebenhoden des Kaninchens. Anat. Anz. 113, 53-61.

Holstein, A.F. (1969) Morphologische Studien am Nebenhoden des Menschen. In Zwanglose Abhandlunger aus dem Gebiet der normalen und pathologischen Anatomie, Vol. 20, pp. 1-91. Georg Thieme, Stuttgart.

Jones, R. \& Glover, T.D. (1973) The effects of castration on the composition of epididymal plasma. J. Reprod. Fert. 34, 405-414.
JONES, R. \& Glover, T.D. (1975) Interrelationships between spermatozoa, the epididymis and epididymal plasma. Biol. J. Linn. Soc. 7, Suppl. 1, 367-384.

Lubicz-NAwrocki, C.M. \& Glover, T.D. (1973) The influence of the testis on the survival of spermatozoa in the epididymis of the golden hamster, Mesocricetus auratus. J. Reprod. Fert. 34, 315-329.

Millar, R.P. (1972) Degradation of spermatozoa in the epididymis of a seasonally breeding mammal, the rock hyrax, Procavia capensis. J. Reprod. Fert. 30, 447-450.

NiCANDER, L. (1957) On the regional histology and cytochemistry of the ductus epididymidis in rabbits. Acta morph. neerl. scand. 1, 99-118.

NiCANDER, L. (1958) Studies on the regional histology and cytochemistry of the ductus epididymidis in stallions, rams and bulls. Acta morph. neerl. scand. 1, 337-362.

NiCANDER, L. (1965) An electron microscopical study of absorbing cells in the posterior caput epididymidis of rabbit. Z. Zellforsch. mikrosk. Anat. 66, 829847.

NiCANDER, L. (1970) On the morphological evidence of secretion and absorption in the epididymis. In Morphological Aspects of Andrology, Vol. 1, pp. 121-124. Eds A. F. Holstein \& E. Horstmann. Grosse, Berlin.

NiCANDER, L. \& Glover, T.D. (1973) Regional histology and fine structure of the epididymal duct in the golden hamster (Mesocricetus auratus). J. Anat. 114, 347-364.

RACEY, P.A. (1973) The viability of spermatozoa after prolonged storage by male and female bats. Periodicum biologorum 75, 201-205.

RACEY, P.A. (1974) The reproductive cycle in male noctule bats, Nyctalus noctula. J. Reprod. Fert. 41, 169-182.

Reid, B.L. \& Cleland, K.W. (1957) The structure and function of the epididymis. I. The histology of the rat epididymis. Aust. J. Zool. 5, 223 246.

ROWE, P.H., SHENTON, J.C. \& GLOVER, T.D. (1973) 
Testosterone levels in peripheral blood plasma of the rabbit under normal and experimental conditions. Acta endocr., Copenh., Suppl. 177, 125.

ScotT, P.P., Greaves, J.P. \& Scotr, M.G. (1960) Reproduction in laboratory animals as a measure of the value of some natural and processed foods. J. Reprod. Fert. 1, 130-138.
SUZUKI, F. (1974) Aspects of the fine structure of the mammalian epididymis. Ph.D. thesis, University of Liverpool.

SuzUKI, F. \& GLover, T.D. (1973) The effect of castration on the epididymal epithelium of the golden hamster (Mesocricetus auratus). J. Reprod. Fert. 35, 584-585.

Received 18 September 1975 